\title{
P01.22. Identification of a peptide biomarker from bromelain, an extract of ananas comosus merr, using LC-SRM/MS
}

\author{
E Secor ${ }^{1 *}$, S Szczepanek², L Guernsey ${ }^{1}$, L Silbart $^{3}$, R Thrall ${ }^{1}$, D Han ${ }^{4}$ \\ From International Research Congress on Integrative Medicine and Health 2012 \\ Portland, Oregon, USA. 15-18 May 2012
}

\section{Purpose}

Bromelain, a pineapple extract, is a complex mixture of proteases and protease inhibitors. Although bromelain $(\mathrm{Br})$ has been used clinically for over 40 years, the active constituents that mediate its anti-inflammatory activity are not thoroughly characterized and no biomarker exists to evaluate absorbed peptides and their potential therapeutic responses.

\section{Methods}

Stem Br (Vital Nutrients lot \# 2890; Middletown, CT), was tested for authenticity and purity. Female C57BL/6J mice, (Jackson Laboratory; Bar Harbor, ME) received one bolus, i.p. injection of $\mathrm{Br}(12 \mathrm{mg} / \mathrm{kg})$ in $0.5 \mathrm{ml}$ of physiological saline and plasma collected at baseline 3, 6, 12 and 24 hours. All procedures were approved by the Animal Care Committee at University of CT Health Center. Post SDS-PAGE in gel digestion, samples (Br raw material, spiked plasma and plasma from i.p. teated animals) were analyzed via LC/MS/MS (Liquid ChromatographyMass Spectrometry-Mass) and LC-SRM/MS (Liquid Chormatography-Selected Reaction Monitoring/Mass Spectrometry). Data were searched using Mascot and Scaffold algorithms.

\section{Results}

Within the $\mathrm{Br}$ raw material we identified 44 proteins of which several were $\mathrm{Br}$-specific including nine proteases, one glycosidase and three protease inhibitors. In $\mathrm{Br}$ spiked plasma, $7 \mathrm{Br}$-specific proteins (ananain, $\mathrm{Br}$ inhibitor, comosain, cysteine proteinase precursor ANll, FB1035 precursor, FBSB precursor and jacalin- like lectin), similar to those found in the $\mathrm{Br}$ raw material, were identified. Within these 7 proteins, $21 \mathrm{Br}$ specific peptides were further identified and characterized based on their ion spectrum and fragmentation patterns including the unique peptide, DYGAVNEVK. Using SRM DYGAVNEVK was identified in plasma of Br-treated mice. The spectral count of DYGAVNEVK peaked at 6 hours and was undetectable by 24 hours.

\section{Conclusion}

This Br peptide could serve as a biomarker to standardize the therapeutic dose or $\mathrm{Br}$ and maximize its clinical utility.

\section{Author details}

${ }^{1}$ University of Connecticut Health Center, Farmington, USA. ${ }^{2}$ Neag Cancer Center, UCHC, Farmington, USA. ${ }^{3}$ Department of Allied Health Sciences, Storrs, USA. ${ }^{4}$ Center for Vascular Biology, UCHC, Farmington, USA.

Published: 12 June 2012

\section{doi:10.1186/1472-6882-12-S1-P22}

Cite this article as: Secor et al.: P01.22. Identification of a peptide

biomarker from bromelain, an extract of ananas comosus merr, using

LC-SRM/MS. BMC Complementary and Alternative Medicine 2012 12(Suppl 1):P22.

${ }^{1}$ University of Connecticut Health Center, Farmington, USA

Full list of author information is available at the end of the article

(C) 2012 Secor et al; licensee BioMed Central Ltd. This is an Open Access article distributed under the terms of the Creative Commons Attribution License (http://creativecommons.org/licenses/by/2.0), which permits unrestricted use, distribution, and reproduction in any medium, provided the original work is properly cited. 